\title{
Determination of field capacity in the Chibunga and Guano
}

\section{rivers micro-basins [version 1; peer review: 2 approved]}

\author{
Benito Mendoza(iD1, Manuel Fiallos', Sandra Iturralde1, Patricio Santillán², \\ Nelly Guananga ${ }^{3}$, Jaime Bejar³, Daniel A. Lowy4 ${ }^{4}$ Imre Vágó (id 5, Zsolt Sándor (iD,6
}

${ }^{1}$ Chimborazo National University, Riobamba, Ecuador

${ }^{2}$ Fujian Agriculture and Forestry University, Fuzhou, China

${ }^{3}$ Escuela Superior Politécnica de Chimborazo, Riobamba, Ecuador

${ }^{4}$ Genesis Sustainable Future Ltd., Sárospatak, Hungary

5Institute of Agrochemistry and Soil Science, University of Debrecen, Debrecen, Hungary

${ }^{6}$ Research Group of Applied Plant Glycobiology, Dama Research Center limited, Kowloon, Hong Kong

V1 First published: 03 Mar 2021, 10:172

https://doi.org/10.12688/f1000research.28143.1

Latest published: 03 Mar 2021, 10:172

https://doi.org/10.12688/f1000research.28143.1

\section{Abstract}

Background: The micro-basins of the Chibunga and Guano rivers are located within the sub-basin of the Chambo River, which starts at the thaw of the Chimborazo, crosses the cities of Guano and Riobamba, and ends in the Chambo River. These rivers are considered fluvial hydrological forces and geological limits of the aquifer, located in this sub-basin. For this reason, our investigation addressed the field capacity in the micro-basins of Chibunga and Guano rivers, to determine the maximum retention potential, i.e., the saturation of water in the soil.

Methods: We investigated the change of precipitation to runoff through the correlations between the characteristics of the soil and its vegetation. We applied the Curve Number (CN) method introduced by the United States Soil Conservation Service (USSCS); this represents an empirical model, which relates the vegetation cover to the geological and topographic conditions of the soil. Along with the geographic information system, the model allows to represent the variation of runoffs for each micro-basin, according to the different land use categories, over the time frame from 2010 to 2014.

Results: We found that the maximum retention potential is directly affected by $\mathrm{CN}$ values, representing the runoff potential. Highest values of 100 belong to the wetlands, urban area, snow, and water, as rain is converted directly into runoff, being impervious areas. The Guano river micro-basin possesses clay soil with $\mathrm{CN}$ of 78 , the soil texture for eucalyptus forest is clay loam, and its $C N$ value, 46 , is the lowest of the data set. Knowledge of field capacity allows to properly evaluate the storage capacity of soil and water conservation.

Conclusions: Results of this work will be useful in the quantification of the water balance, to determine the water supply and demand.

\section{Open Peer Review \\ Approval Status \\ 12 \\ version 1 \\ 03 Mar 2021

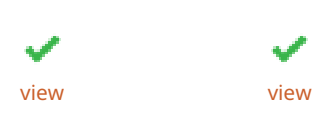 \\ 1. Holger Benavides-Muñoz (iD), Universidad Técnica Particular de Loja (UTPL), Loja, Ecuador \\ 2. Dwita Sutjiningsih, Universitas Indonesia, \\ Depok, Indonesia}

Any reports and responses or comments on the article can be found at the end of the article. 


\section{Keywords}

Field capacity, maximum retention potential, precipitation-runoff relationship, curve number method

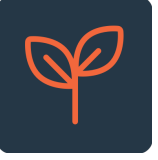

This article is included in the Agriculture, Food and Nutrition gateway.

Corresponding author: Zsolt Sándor (sandor@edu.damaresearch.com)

Author roles: Mendoza B: Conceptualization, Investigation, Methodology, Project Administration, Resources, Supervision, Validation, Writing - Original Draft Preparation, Writing - Review \& Editing; Fiallos M: Investigation, Methodology, Project Administration, Writing Original Draft Preparation; Iturralde S: Investigation, Methodology, Project Administration, Writing - Original Draft Preparation; Santillán P: Investigation, Methodology, Project Administration, Writing - Original Draft Preparation; Guananga N: Investigation, Methodology, Project Administration, Writing - Original Draft Preparation; Bejar J: Investigation, Methodology, Project Administration, Writing - Original Draft Preparation; Lowy DA: Investigation, Methodology, Project Administration, Visualization, Writing - Original Draft Preparation, Writing - Review \& Editing; Vágó I: Project Administration, Writing - Original Draft Preparation, Writing - Review \& Editing; Sándor Z: Investigation, Methodology, Writing - Original Draft Preparation

Competing interests: No competing interests were disclosed.

Grant information: The author(s) declared that no grants were involved in supporting this work.

Copyright: $\odot 2021$ Mendoza B et al. This is an open access article distributed under the terms of the Creative Commons Attribution License, which permits unrestricted use, distribution, and reproduction in any medium, provided the original work is properly cited.

How to cite this article: Mendoza B, Fiallos $\mathrm{M}$, Iturralde $\mathrm{S}$ et al. Determination of field capacity in the Chibunga and Guano rivers micro-basins [version 1; peer review: 2 approved] F1000Research 2021, 10:172 https://doi.org/10.12688/f1000research.28143.1

First published: 03 Mar 2021, 10:172 https://doi.org/10.12688/f1000research.28143.1 


\section{Introduction}

The most important natural resources are soil (Bautista et al., 2018; Mátyás et al., 2018; Singla et al., 2018; Sukiasyan \& Kirakosyan, 2020), air (DRC, 2020), and water (Bersosa et al., 2019). Therefore, protection of natural resources and their rational use are essential to provide sustainable environmental and agricultural management practices (Mátyás et al., 2020; Sándor et al., 2020; Shomana et al., 2020). The hydrological cycle is the process of water circulation in the earth, therefore, it is important to study surface and underground water, to understand the cycle in a global way and its interrelation with the environment (Pacheco Moya et al., 2018).

Also, the management of a basin must be oriented to the rational use of its resources, i.e., to order and spatially distribute their use (Sánchez-Cohen et al., 2015). Management is important, as a basin has environmental, social, economic, and cultural implications in the distribution of water resources (Sánchez-Cohen et al., 2015). As of today, in Ecuador, most of the hydrographic basins do not have proper conservation management, causing alterations in the hydrological cycle and generating for a given area little retention of humidity, erosion, and flooding over periods of rain and water scarcity in dry periods (Lizárraga-Mendiola et al., 2019).

Surface runoff is part of the hydrological cycle; it occurs as a result of excess water, which that does not filter off, and collects in the secondary channels, and finally ends up in the main channel, until it reaches the mouth of the river (Francés \& Montalvo, 2017). When this process is not adequately controlled, it becomes a critical environmental problem, as it favors water erosion of the soil, rivers overflow, increasing the sediment load, and, by dragging, it causes water contamination (Alonso-Brito, 2016). Various study techniques have been developed, both empirically and in the field (Maidment et al., 1994), which allow determination of the volume of runoff in a given area, for providing adequate water management (Amy, 1974). These techniques enable appropriate design structures for the use and control of water resources. Surface and underground runoffs depend on the hydraulic characteristics of the subsoil, such as hydraulic conductance and porosity, which are distributed according to the geological and topographic soil conditions (Lee et al., 2015).

As a result, runoff calculations can be derived from precipitation events, using correlations between the characteristics of the soil and its vegetation, and also taking into account the interaction of different components of the natural system (Pacheco Moya et al., 2018). Nevertheless, the hydro-meteorological information in the hydrographic basins is limited in terms of a rainfall and river database of several years, as there is no good hydro-meteorological network in Ecuador (Ochoa-Tocachi et al., 2018), and this data is needed for hydrological modeling of water balance, when calculating water supply and demand (Zubieta et al., 2018).
Therefore, one can apply empirical models that provide approximate data on the hydrological reality of an area, e.g., for runoff the Curve Number $(\mathrm{CN})$ method is used (Uwizeyimana et al., 2019).

The goal of this work is to determine the field capacity, considering the physical characteristics of the environment and the use of the soil and vegetation cover. We aim to obtain quantitative values for $\mathrm{CN}$, and to determine the maximum potential retention and the precipitation-runoff relationship. These calculations are done for the Chibunga and Guano rivers micro-basins, located in the province of Chimborazo, Ecuador. This work should be helpful in quantifying the water balance in a basin, and to determine water supply and demand in a more efficient manner.

\section{Methods}

Description of study area

Our study was conducted from January 7 to March 29, 2019, in the area of interest, namely, the micro-basins of the Chibunga and Guano rivers, which are part of the sub-basin of the Chambo River, in the province of Chimborazo. Economic activity, which predominates in the region is agriculture, providing living means for most families residing there. Chibunga river originates from the slopes of the Chimborazo Volcano and descends through the Arenal moorland, until it reaches agricultural areas in San Juan town, and the communities including Chimborazo, Shobol Llinllin, with the name arising from Rio Chimborazo. Next, it joins the Cajabamba river at 3,238 $\mathrm{m}$ above sea level, and becomes Chibunga river (Mayorga \& Carbonel, 2018). This micro-basin extends over $38 \mathrm{~km}$, extends from northwest to southeast, and is the main tributary of the Chambo River at the Northern extremity of the Amazon region of Ecuador (at $680 \mathrm{~km}$ from the Amazonas River) (CNRH, 2007). The Guano River micro-basin is born on the slopes of the Chimborazo Volcano and receives contributions to its channel from streams, such as Cascajal, Chuquipogio, Abras, Puluchaca, Patulú, Igualata, Asaco, and others (Cevallos Gaibor, 2015). Its approximate area is 37,061 ha, and most of its water is used in the Guano Canton (Mendoza, 2016) until it eventually flows into the Chambo River.

\section{Identification of the sampling points}

Sampling points were identified by the over position of geology and elevation layer, where the most representative categories concerning land use were identified: $\mathrm{Pa}$ (moorland), $\mathrm{Hu}$ (wetlands), Bs (forest), $\mathrm{Na}$ (snow and water), $\mathrm{Z}$ (urban area), $\mathrm{C}$ (crops), Se (eroded soil), and Ps (grass).

Subsequently, the following criteria were considered to determine the sampling points:

- Areas with steep slopes and poor accessibility were excluded

- Areas with a high degree of water for field tests were included 
- Categories of urban area, snow, and water were excluded because of their impervious surface.

\section{Obtaining the needed parameters for CN}

The $\mathrm{CN}$ parameter measured in the field (in-situ) and laboratory. First, the infiltration capacity was determined by infiltrometer (model 09.04, SDEC France, France). Second, soil characterization was done for permeability, texture, porosity, and organic matter (Tailor \& Shrimali, 2016).

\section{In-situ analysis}

At each sampling point, infiltration tests were performed with by means of a double ring infiltrometer (Model 09.04, SDEC France, France). Briefly, two concentric rings were set up on a portion of soil and water was poured into the outer ring. Variation of the water level in the inner ring was measured to determine infiltration of the soil (Carreras Nampulá et al., 2015). Samples should be as little disturbed as possible, for not altering the results.

\section{Analysis in the laboratory}

Figure 1 shows a total of 23 points corresponding to the Chibunga river micro-basin and 21 points for the Guano river micro-basin, which were used for sampling. Five soil samples were taken from each sampling point, with the excavation being every $0.40 \mathrm{~m}$ to a maximum depth of $2.0 \mathrm{~m}$, within a circular area $0.50 \mathrm{~m}$ in diameter. A total of $2 \mathrm{~kg}$ of soil were taken by a tubular soil sampler (15'L x 3/4”Dia,

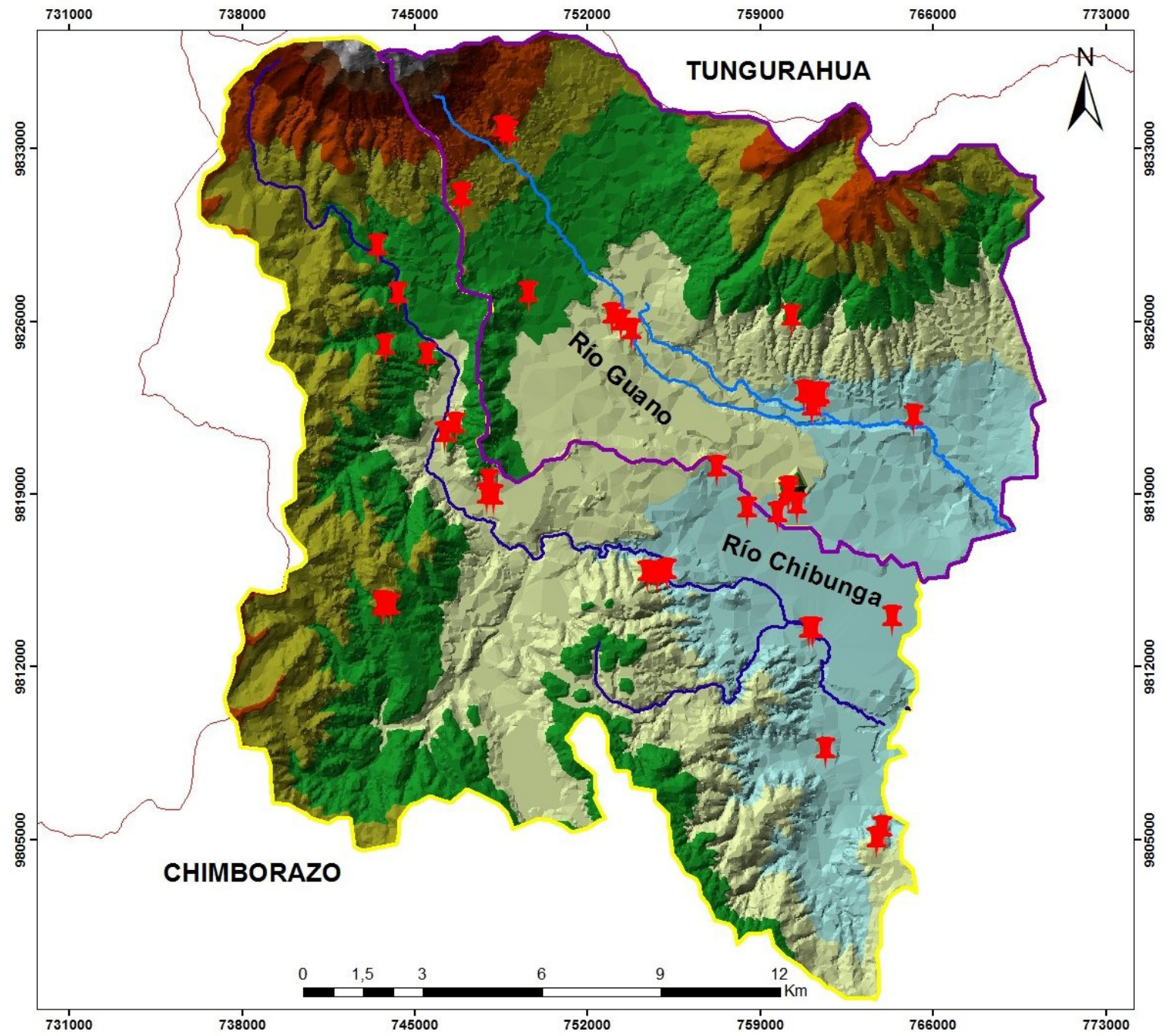

Figure 1. Location of the Chibunga and Guano rivers micro-basins. The red pins correspond to the Chibunga and Guano river micro-basins. Figure 1 was adapted from satellite images to identify the categories of land use and vegetation cover. These images were downloaded from the Copernicus website, using the Sentinel 2A satellite (Immitzer et al., 2016) (data is open source once a user registers for access).The images are from 2013, 2014, and 2018. 
Accuproducts International, USA) for each point, were placed in sampling bags $(125 \mathrm{~mm} \times 225 \mathrm{~mm}$, Geology Superstore, United Kingdom), and transported to the Environmental Services Laboratory to determine the permeability, texture, porosity, and organic matter.

Soil texture was determined according to the USDA triangle of textural classes (Bautista Carrascosa \& Oliver Talens, 2017), applying the organoleptic method. Briefly, numerical values were assigned within the range of $1-12$ to define granulometry: lower numbers (1-5), represent fine granulometry, such as clay and loam clay type; mid numbers (6-9) correspond to medium granulometry, such as loams and silts soils; while high numbers (10-12), are for coarse granulometry, such as sands.

Porosity was obtained by a literature method (Liu et al., 2017), which relies on the real and apparent density of the soil. Calculations were based on Equation (1), which can be applied to each soil class, identified in the study area.

$$
P[\%]=\left(1-\frac{D a\left[\frac{\mathrm{g}}{\mathrm{cm}^{3}}\right]}{D r\left[\frac{\mathrm{g}}{\mathrm{cm}^{3}}\right]}\right) * 100
$$

Where:

$\mathrm{P}=$ Total porosity of the soil sample, [\%]

$\mathrm{Da}=$ Apparent density of the soil, $\left[\mathrm{g} / \mathrm{cm}^{3}\right]$

Dr $=$ Real particle density, $\left[\mathrm{g} / \mathrm{cm}^{3}\right]$

Permeability or hydraulic conductivity (Papierowska et al., 2018) was calculated using a permeameter (with internal diameter $\mathrm{D}=6.4 \mathrm{~cm}$, height $\mathrm{L}=15.3 \mathrm{~cm}$ ) (Cotecno Falling Head Permeameter, Santiago, Chile), in which $h$ values are measured, obtained for various times elapsed from the beginning of the test. Then, the soil permeability coefficient, $k$, is calculated using Darcy's Law, according to Equation (2) and Equation (3), (Wang et al., 2020):

$$
\begin{gathered}
Q=\frac{H_{3}-H_{4}}{L} * A * k \\
k=\frac{Q * L}{\left(H_{3}-H_{4}\right) * A}
\end{gathered}
$$

Where: $\mathrm{Q}=$ flow, expressed in $\mathrm{m}^{3} / \mathrm{s} ; \mathrm{L}=$ length of sample $(\mathrm{m})$; $\mathrm{k}$ = Darcy's permeability coefficient, variable as a function of the sample material, expressed in $\mathrm{m} / \mathrm{s} ; \mathrm{A}=$ cross-sectional area of the sample $\left(\mathrm{m}^{2}\right) ; \mathrm{H}_{3}=$ height, above the water level in reference tube placed at the entrance of the filter layer; $\mathrm{H}_{4}$ =height, above the reference level, that reaches the water in a tube placed at the out of the filter layer.

Organic matter was determined via calcination of the samples to later calculate the weight loss, which corresponds to the organic compounds present in the samples (Papierowska et al., 2018). The following procedure was used: crucibles with samples were measured in triplicate. Samples were subjected to $105{ }^{\circ} \mathrm{C}$ for $2 \mathrm{~h}$; then, the temperature was raised to $550{ }^{\circ} \mathrm{C}$ for $2 \mathrm{~h}$. At the end, samples were cooled for $2 \mathrm{~h}$ inside the muffle. Subsequently, samples are returned to the oven at $105{ }^{\circ} \mathrm{C}$ for $30 \mathrm{~min}$, to stabilize their temperature and eliminate moisture remained in the samples, then cooled in the desiccator, and finally weighed for determining the weight loss of each sample. Soil organic matter (SOM) was determined gravimetrically and calculated according to (Equation 4).

$$
\begin{aligned}
& \text { SOM } \%=\left[\left(\text { Weight at } 105^{\circ} \mathrm{C}\right)-\left(\text { Weight at } 550^{\circ} \mathrm{C} \text { calcination }\right) /\right. \\
& \left.\left(\text { Weight at } 105^{\circ} \mathrm{C}\right)\right] .100
\end{aligned}
$$

\section{Curve number calculation (CNRH)}

CN was determined according to the SCS method, a technique developed for infiltration proofs depending on the runoff generating properties. The procedure considered: the hydrological group of soil (HGS), the previous humidity condition, the use of the land and treatment within the hydrographic basin. A value is calculated, which estimates the soil condition with regard to its usefulness (Satheeshkumar et al., 2017). CN is a curve number, obtained from cross-tabulation in spatial digital format, processed by soil and geomorphology maps, generating the hydrological groups $(\mathrm{GH})$, as described in the SCS Handbook of Hydrology (NEH-4), Section-4 (USDA 1972). CN can be expressed by Equation (5).

$$
C N=\frac{25400}{(254+S)}
$$

where:

$$
S=\frac{25400}{C N}-254
$$

Taking as the input values of the $\mathrm{CN}$ parameter, the field capacity or maximum retention potential (S) was determined as the relatively constant amount of water contained by a saturated soil, after $48 \mathrm{~h}$ of drainage (Wróbel \& Boczoń, 2020). Hence, there is a relationship between the soil and the coverage conditions within the micro-watersheds, via $\mathrm{CN}$ values. Numbers are shown on a scale from 0 to 100 ; the greater the number, the greater the direct runoff volume that can be expected from a storm (Lian et al., 2020).

\section{Rainfall-effective runoff ratio}

Precipitation values were obtained from the interpolation by the kriging method, by using data from 6 meteorological stations (Table 1), over the time encompassing years 2010-2015. Precipitation values can be calculated using Equation (7) (Naranjo, 2014)

$$
\hat{Z}\left(S_{0}\right)=\sum_{i=1}^{N} \lambda_{i} Z\left(S_{i}\right)
$$

$\mathrm{Z}\left(\mathrm{s}_{\mathrm{i}}\right)=$ the value measured at location

$\lambda_{\mathrm{i}}=$ an unknown weight for the value measured at location

$\mathrm{S}_{0}=$ the location of the prediction

$\mathrm{N}=$ the number of measured values 
Table 1. Precipitation values provided by meteorological stations between 2010 and 2015 .

\begin{tabular}{|c|c|c|c|c|c|c|c|c|c|c|}
\hline Id & code & Stattion name & $\mathbf{x}$ & $y$ & 2010 & 2011 & 2012 & 2013 & 2014 & 2015 \\
\hline 1 & H0786 & Guamote aj Cebadas & 763003 & 9792069 & 1389.55 & 1092.22 & 1433.7 & 1048.05 & 1219.11 & 1429.52 \\
\hline 2 & H0333 & San Lorenzo en san Lorenzo & 722749 & 9813081 & 1265.69 & 1184.1 & 1337.9 & 928.23 & 917.57 & 1852.97 \\
\hline 3 & H0787 & Alao en hda. Alao & 776829 & 9792312 & 995.39 & 1046.21 & 1040.52 & 1101.64 & 786.65 & 1693.36 \\
\hline 4 & H0788 & Puela aj Chambo & 780994 & 9832690 & 1551.5 & 1576.63 & 1611.57 & 1604.05 & 1589.55 & 2480.86 \\
\hline 5 & H0789 & Guargualla aj Cebadas & 766422 & 9792692 & 807.94 & 990.75 & 1013.13 & 1061.11 & 714.824 & 1370.87 \\
\hline 6 & H0790 & Cebadas aj Guamote & 762724 & 9791230 & 921.985 & 1020.37 & 861.78 & 787.13 & 762.901 & 1246.18 \\
\hline
\end{tabular}

Similarly, for runoff, the maximum retention potential was analyzed as a function of yearly precipitation. By this, one obtained the total flow, based on the vegetation cover (Sikorska et al., 2018).

For the multitemporal study the following methodology was used, all methods described below being applied for each sampling site:

Supervised Classification Criteria: Study areas should match the number of categories that are intended to be analyzed (TELEDET, 2017). The areas must be correctly identified to cover all classes and must be homogeneous. Also, in supervised classification uniband statistical analysis verifies that values resemble normal distribution. To meet these criteria, we used the following classic algorithms: classifier by minimum distance, by parallelepipeds, and by maximum probability (Acosta, 2017).

\section{Classification methods}

\section{Minimum Distance}

With this classifier collected data is used to determine the mean of the classes selected at the study sites. This approach assigns each unidentified pixel to the class with the closest mean. For the closest mean values one can use the Euclidean distance between the pixel and the center of each class. Although simple from the computational standpoint, this algorithm has certain limitations, including the insensitivity to different degrees of variance in the spectral responses (TELEDET, 2017).

\section{Maximum Likelihood (ML)}

ML or maximum probability assumes that the reflectivity values in each class follow a multivariate normal probability distribution. The vector of means and the variance-covariance matrix are then used to estimate the probability by which one given pixel belongs to all classes. Finally, pixels were assigned to the class to which it belonged with the highest probability (Tso \& Mather, 2009). A Bayesian approach was used and considered was the a priori probability, whether a pixel belonged to a certain class. The greater the surface area, the greater the probability that a pixel belongs to it (Toro et al., 2013).

\section{Contingency table}

It consists of a double-entry table, which compares the real values with results obtained in the classification. The diagonal of the matrix reveals the number of real pixels and the classification that coincides by category, while the remaining pixels indicate the ones that may be confused with other categories. One represents vertically the percentage of real pixels that were confused in the truth-terrain, while horizontally one shows the percentage of all pixels (Borràs et al., 2017).

\section{Kappa coefficient}

The accuracy measures considered by us are simple to use, being based on either the main diagonal, or the rows and columns of the contingency table. In some cases, a totally random distribution of pixels in the classes can yield apparently correct results in the contingency table (TELEDET, 2017).

\section{Results and discussion}

Through the multi-temporal study and the application of spectral signatures, eight categories of vegetation cover were identified for each micro-basin: $\mathrm{Pa}$ (moorland), $\mathrm{Hu}$ (wetlands), Bs (forest), $\mathrm{Na}$ (snow and water), Z (urban area), C (crops), Se (eroded soil), and Ps (grass). The 26 sampling points were in the Chibunga river micro-basin and 23 points in the Guano river micro-basin.

Physical characteristics of the soil from each sampling point were determined, including porosity, permeability, and infiltration capacity (Table 2). These unique values are required to determine vegetation cover and soil texture, necessary to calculate $\mathrm{CN}$.

Table 3 lists the values for CN and HSG (hydrological group) depending on the state of conservation and conditions present in the sampling area.

In Table 3 one finds different combinations of vegetation cover and the HSGs of the soil in the micro-basin of the Chibunga River, where each combination corresponds to a $\mathrm{CN}$ that represents the runoff potential, in which the highest values belong to the wetlands, urban area, snow, and water, assigning them the value of 100 . In these areas rain is converted 


\section{Table 2. Physical characteristics of the soil of the Chibunga and Guano rivers micro-basin.}

\begin{tabular}{|l|l|l|l|l|l|l|l|}
\hline \multicolumn{4}{|c}{ Chibunga river micro-basin } & \multicolumn{3}{c|}{ Guano river micro-basin } \\
\hline Class & Poro. & Perm. & Cap. Infil. & Poro. & Perm. & Cap. Infil. \\
\hline $\mathrm{Pa}$ & 0.45 & $2.3 \mathrm{E}-04$ & 96.5 & 0.58 & $3.1 \mathrm{E}-04$ & 183.2 \\
\hline $\mathrm{Hu}$ & null & null & null & null & null & null \\
\hline $\mathrm{BS}$ & 0.58 & $1.2 \mathrm{E}-04$ & 592.4 & 0.52 & $1.5 \mathrm{E}-04$ & 60.2 \\
\hline $\mathrm{Na}$ & null & null & null & null & null & null \\
\hline Z & null & null & null & null & null & null \\
\hline Se & 0.53 & $2.8 \mathrm{E}-05$ & 120.3 & 0.48 & $2.2 \mathrm{E}-04$ & 230.4 \\
\hline C & 0.35 & $5.4 \mathrm{E}-04$ & 118.6 & 0.50 & $3.2 \mathrm{E}-04$ & 45.8 \\
\hline Ps & 0.44 & $1.1 \mathrm{E}-04$ & 108.7 & 0.53 & $1.6 \mathrm{E}-04$ & 174.4 \\
\hline
\end{tabular}

$\mathrm{Pa}$ (moorland), Hu (wetlands), Bs (forest), $\mathrm{Na}$ (snow and water), Z (urban area), C (crops), Se (eroded soil), and Ps (grass). Null values mean 0 or minute areas.

Abbreviations: Poro., porosity; Perm., permeability; Cap. Infil., infiltration capacity.

\begin{tabular}{|c|c|c|c|c|c|c|}
\hline \multicolumn{4}{|c|}{ Chibunga river micro-basin } & \multicolumn{3}{|c|}{ Guano river micro-basin } \\
\hline Class & Texture & HSG & $\mathrm{CN}$ & Texture & HSG & $\mathrm{CN}$ \\
\hline $\mathrm{Pa}$ & Silty clay & $\mathrm{D}$ & 78 & Clay & $\mathrm{D}$ & 78 \\
\hline $\mathrm{Hu}$ & Null & Null & 100 & Null & Null & 100 \\
\hline Bs & Silty clay & $\mathrm{D}$ & 79 & Clay loam & $\mathrm{D}$ & 46 \\
\hline $\mathrm{Na}$ & Null & Null & 100 & Null & Null & 100 \\
\hline Z & Null & Null & 100 & Null & Null & 100 \\
\hline Se & Clay loam & $\mathrm{D}$ & 88 & Silty clay loam & $\mathrm{D}$ & 88 \\
\hline C & Clay & $\mathrm{D}$ & 89 & Sandy clay & $\mathrm{D}$ & 80 \\
\hline Ps & Silty clay & $\mathrm{D}$ & 79 & Sandy clay & $D$ & 78 \\
\hline
\end{tabular}

Abbreviations: Poro., porosity; Perm., permeability; Cap. Infil., infiltration capacity.

directly to runoff, as they are impervious areas. By contrast, the Guano River micro-basin revealed that the moorland class had clay soil with $\mathrm{CN}$ of 78 , the soil texture for eucalyptus forest was silty clay, and its $\mathrm{CN}$ was the lowest of the data set (46).

\section{The maximum retention potential (S)}

In Figure 2, the "S" values (Lian et al., 2020) are shown for the Chibunga River micro-basin for years 2013 and 2014. One can observe a low $\mathrm{CN}$ value (orange color) in the range of 1-52 $\mathrm{mm}$ of water retained in the soil. Highest values of the water retention potential in the study area are highlighted in yellow; they correspond to moorlands and coniferous forests. In the micro-basin of the Guano River, we uncovered water retention potential values of $0 \mathrm{~mm}$ (red color). Such areas are characterized by the presence of urbanization, bodies of water, and snow. On the opposite end, highest values of water retention correspond to areas with eucalyptus forests (blue color), which are located in the middle part of the micro-basin. 


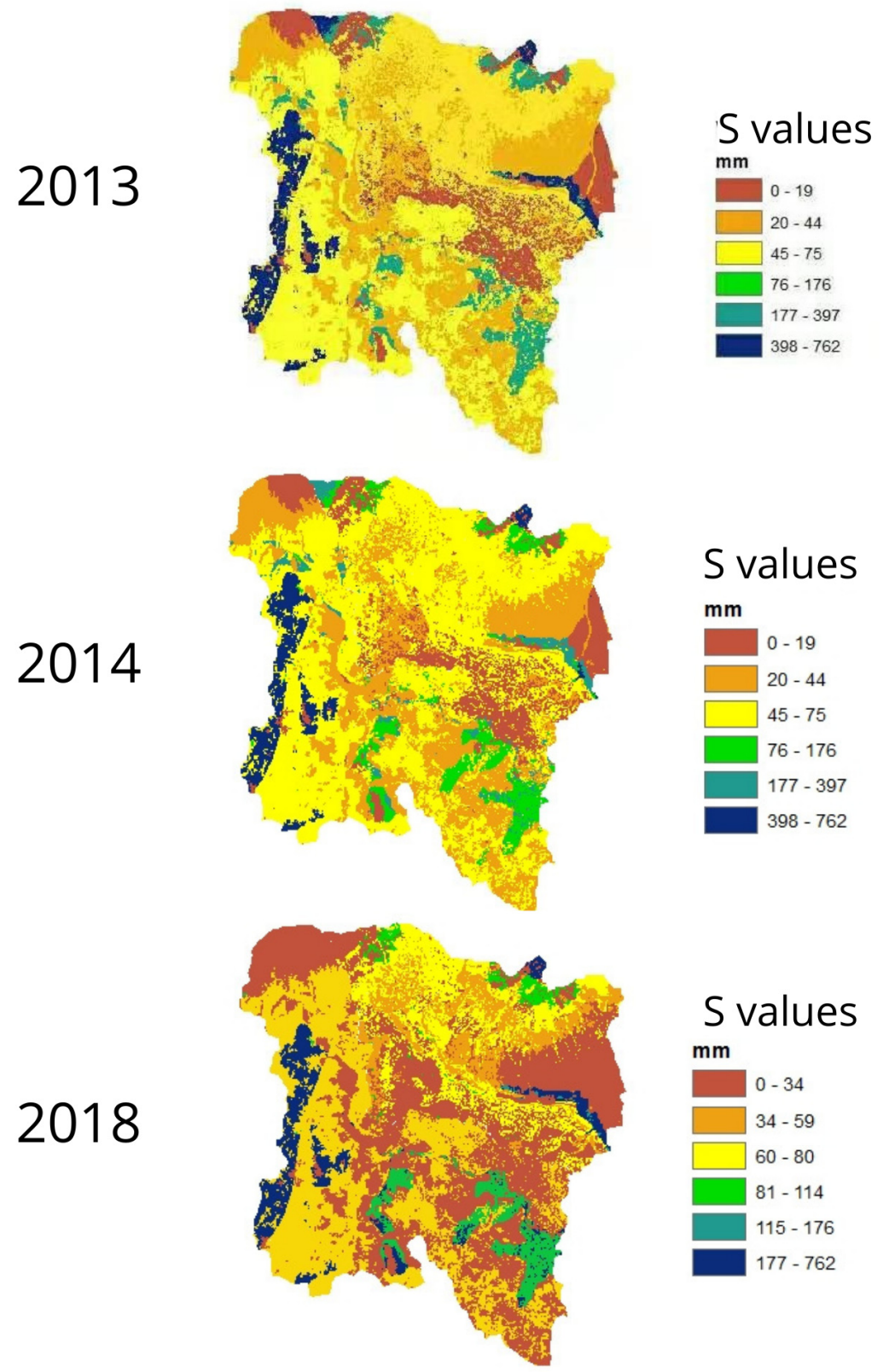

Figure 2. Maps of maximum retention potential of the Chibunga and Guano rivers micro-basins.

One should emphasize that the vegetation cover in this area has not changed over the three years when the multitemporal study was conducted.

\section{Precipitation-runoff ratio}

In Figure 3, the variation of precipitation is shown over the 3 years of our multitemporal study. Our findings agree with a prior study of Chidichimo and co-workers, according to which highest precipitation occurs over the months of March, April, and May, while minimum precipitation values are recorded in January, November, and December (Chidichimo et al., 2018).

The values of precipitation-runoff in the micro-basins were obtained via the curve number method $(\mathrm{CN})$. Values of maximum retention potential were found to the vegetation cover for years 2013, 2014, and 2018.

In Figure 4, the precipitation-runoff relationship is much higher for an urban area in 2018 with a similar value of $44.6 \mathrm{~mm}$, and 


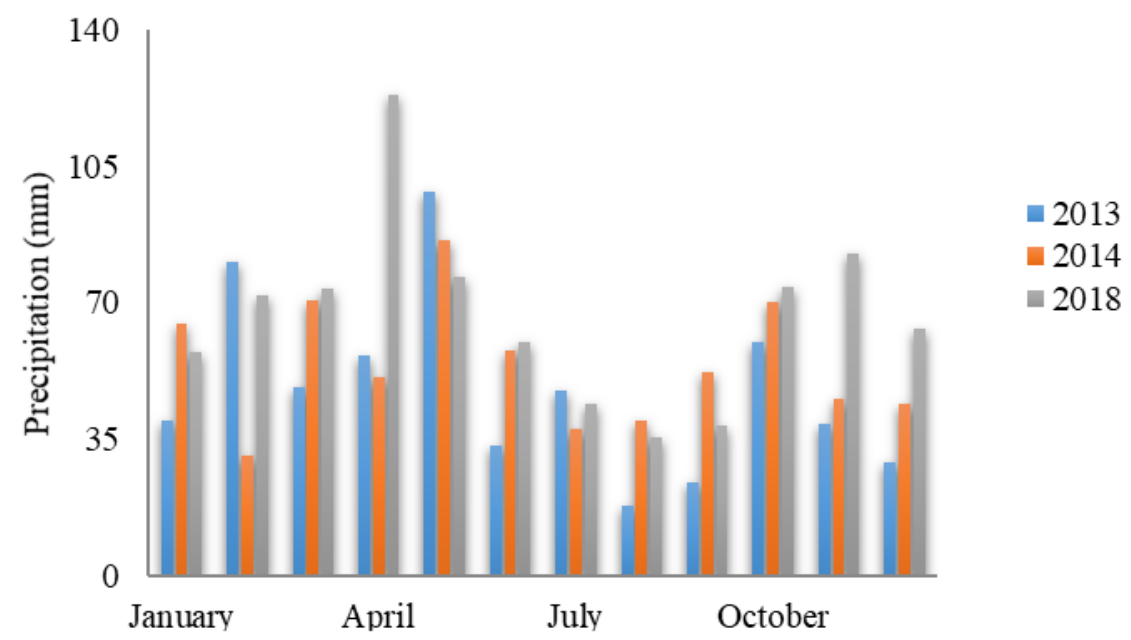

Figure 3. Average monthly precipitation.

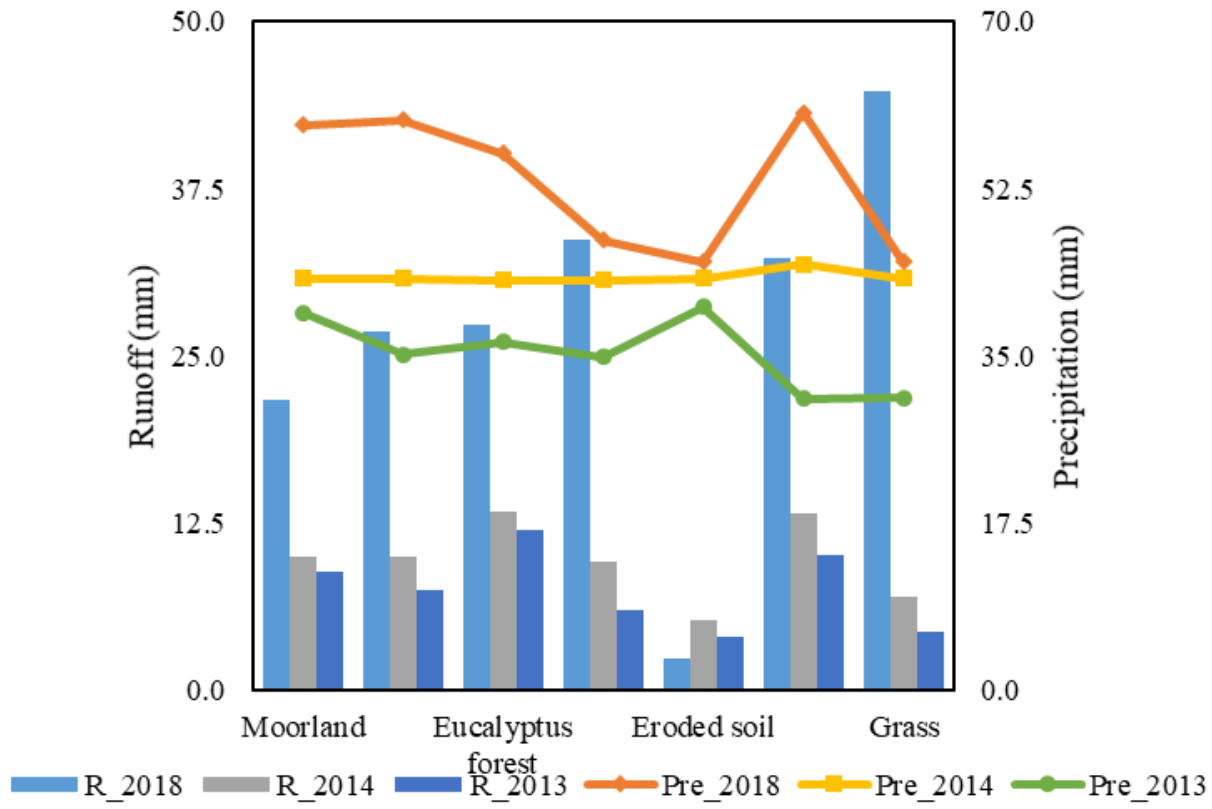

Figure 4. Precipitation-runoff relationship of the Chibunga river micro-basin.

a $\mathrm{CN}$ of 100 , due to its retention capacity which is 0 . On the other hand, we obtained for vegetable crops and eucalyptus forests a similar value of $13 \mathrm{~mm}$ of runoff in 2014 and the retention capacity was of 60 and $68 \mathrm{~mm}$ of water in the soil, respectively. Therefore, it was determined that the grass category in 2013 had the lowest runoff at $4.4 \mathrm{~mm}$ and a $\mathrm{CN}$ of 79 , demonstrating the saturation of porous medium in silty clay soil.
Figure 5 reveals that in 2013, vegetable crops have a runoff of $12.7 \mathrm{~mm}$ and an average annual rainfall of $32.5 \mathrm{~mm}$, while in 2014 and 2018, the urban area, wetlands, and eroded soil was in the range of $27-44 \mathrm{~mm}$ of runoff, showing retention of water of $0 \mathrm{~mm}$ in the soil. In addition, the greatest values of precipitation were found in 2018 for moorland category with $59.2 \mathrm{~mm}$ and runoff of $21.7 \mathrm{~mm}$ in the precipitation-runoff 


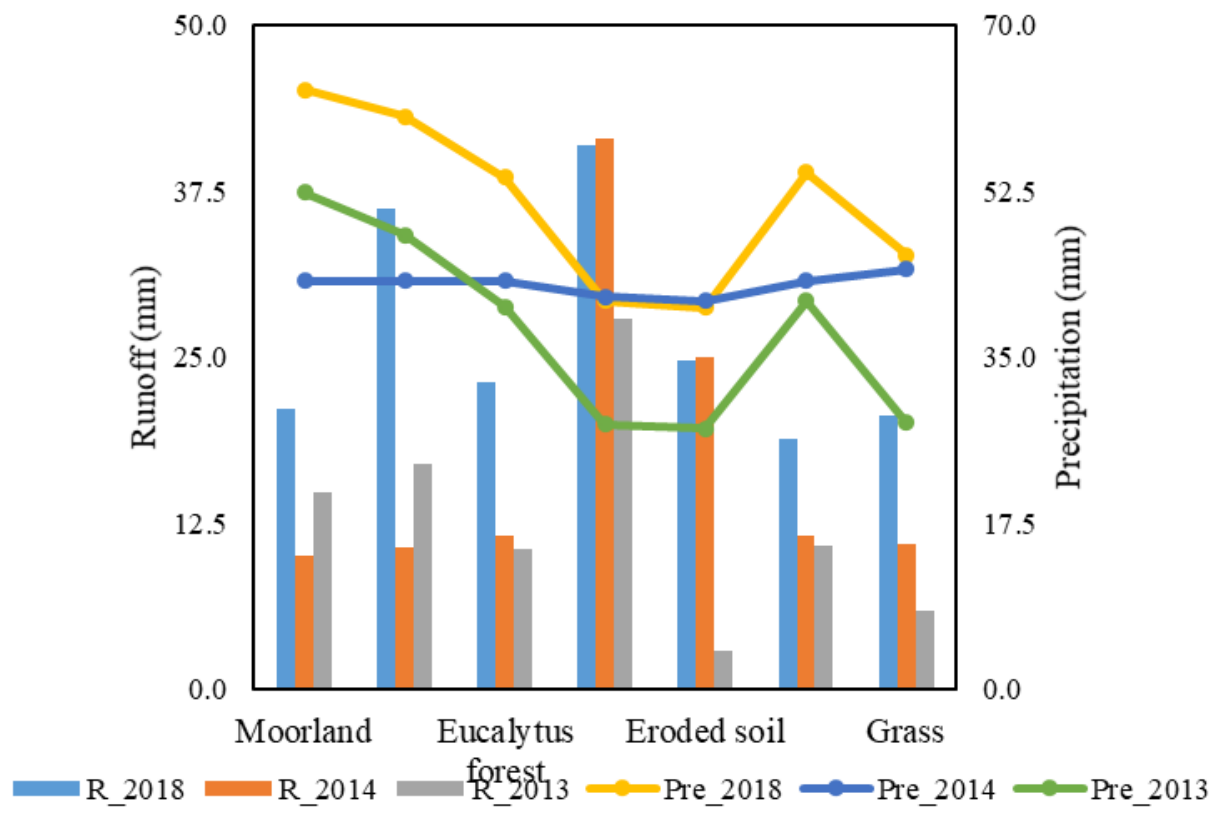

Figure 5. Precipitation-runoff relationship for the year 2014, 2013 and 2018 of the Guano river micro-basin.

conversion, while the retention value is $72 \mathrm{~mm}$ of water, indicating the saturation of the porous medium in the soil.

\section{Conclusion}

The maximum retention potential is directly affected by the $\mathrm{CN}$ values that are recorded according to the conditions and use of the vegetation cover on the land. The categories snow, and water, wetlands, and urban area showed null retention of water in the soil because their transformation is directly from precipitation to runoff. This trend was opposite for the other categories, with the highest values in the maximum retention potential, while their values of runoff decreased.

To better understand the water storage capacity, we had to adequately interpret the values of field capacity. This was done by relating the water storage capacity to permeability, porosity, and the amount of organic matter. Obtained values allowed the formulation of adequate recovery or conservation measures to achieve better retention of water in the soil.

\section{Data availability}

Underlying data

Figshare: GPS Coordinates of Sampling Points in Guano and Chibunga basins, https://doi.org/10.6084/m9.figshare.13874696.v1 (Mendoza et al., 2021).

Figshare: Raw data Chibunga, https://doi.org/10.6084/m9.figshare. 13875050.v1 (Melendez, 2021).

Figshare: Supporting data: Guano (Recuperado).xlsx, https:// doi.org/10.6084/m9.figshare.13299686.v1 (Dama Research Center Limited, 2020).

Data are available under the terms of the Creative Commons Attribution 4.0 International license (CC-BY 4.0).
Acosta Gutiérrez, M: Alternativa de ejercicios físicos en agua para la Rehabilitación en pacientes hemipléjicos por infarto Cerebral en el municipio gibara. MS thesis. Facultad de Cultura Física, 2017. Reference Source

Alonso-Brito GR: Predicción probabilística del escurrimiento superficial y la pérdida de sedimento para eventos extremos. Parte II. Revista Ciencias Técnicas Agropecuarias. 2016; 25(4): 4-16.

Publisher Full Text
Amy G: Water quality management planning for urban runoff: US Environmental Protection Agency. 1974.

Reference Source

Bautista Carrascosa MI, Oliver Talens J: DETERMINACIÓN DE LA TEXTURA AL TACTO. 2017.

Reference Source

Bautista G, Mátyás B, Carpio I, et al.: Unexpected results in Chernozem soil respiration while measuring the effect of a bio-fertilizer on soil microbial 
activity [version 2; peer review: 2 approved]. F1000Res. 2018; 6: 1950. PubMed Abstract | Publisher Full Text | Free Full Text

Bersosa F, Calderón V, Sanchez R, et al.: A study of biodiversity and water quality by analyzing aquatic macroinvertebrates in the Pasochoa Wildlife Refuge, Ecuador. Appl Ecol Environ Res. 2019; 17(2): 4949-4956. Publisher Full Text

Borràs J, Delegido J, Pezzola A, et al.: Clasificación de usos del suelo a partir de imágenes Sentinel-2. Revista de Teledetección. 2017; 48: 55-66. Publisher Full Text

Carreras Nampulá J, Lara G, CM EM, et al.: Análisis de la intensidad y duración de la lluvia simulada mediante manipulación manual, para el diseño y construcción de un simulador de lluvias. Revista de Ciencias de la unicach. 2015; 9(2): 73-78.

Cevallos Gaibor CF: Caracterización de la calidad hídrica de la Microcuenca del río Guano. Escuela Superior Politécnica de Chimborazo. 2015.

Reference Source

Chidichimo F, Mendoza BT, De Biase M, et al.: Hydrogeological modeling of the groundwater recharge feeding the Chambo aquifer, Ecuador. AIP Conference Proceedings. AIP Publishing LLC, 2018; 2022(1): 020003. Publisher Full Text

CNRH: Estudio Hidrológico de la subcuenca del río Chambo

implementación de un modelo hidrológico. (Quito, Ecuado). 2007.

Reference Source

Dama Research Center limited, Mendoza B: Supporting data: Guano (Recuperado).xlsx. figshare. Dataset. 2020.

http://www.doi.org/10.6084/m9.figshare.13299686.v1

DRC: Effect of transport measures and curfew against COVID-19 spread on air pollution (TSP) in Ecuador's three most populous cities. DRC Sustainable Future. 2020; 1(1): 54-59.

Publisher Full Text

Francés F, Montalvo C: Análisis integral del impacto del Cambio Climático en los regímenes de agua, crecidas y sedimentos de una rambla mediterránea. Ingeniería del agua. 2017; 21(4): 263-272.

Publisher Full Text

Immitzer M, Vuolo F, Atzberger C: First experience with Sentinel-2 data for crop and tree species classifications in central Europe. Remote Sens. 2016; 8(3): 166

Publisher Full Text

Lee $\mathrm{BJ}$, Lee $\mathrm{JH}$, Yoon $\mathrm{H}$, et al.: Hydraulic experiments for determination of in situ hydraulic conductivity of submerged sediments. Sci Rep. 2015; 5: 7917. PubMed Abstract | Publisher Full Text | Free Full Text

Lian $\mathrm{H}$, Yen $\mathrm{H}$, Huang $\mathrm{C}$, et al.: CN-China: Revised runoff curve number by using rainfall-runoff events data in China. Water Res. 2020; 177: 115767. PubMed Abstract | Publisher Full Text

Liu Z, Dugan B, Masiello CA, et al:: Biochar particle size, shape, and porosity act together to influence soil water properties. PLOS One. 2017; 12(6): 0179079 .

PubMed Abstract | Publisher Full Text | Free Full Text

Lizárraga-Mendiola L, Alzati CAB, García FOL: Uso de tecnologías de bajo impacto como alternativa para la restauración del ciclo hidrológico en zonas urbanas: Campus universitario de la UAEH, como caso de estudio. Vivienda y Comunidades Sustentables. 2019; (5): 23-32. Publisher Full Text

Maidment DR, Mays L, Larry W: Hidrología aplicada. Aguas superficiales. 1994; 146.

Mayorga NCV, Carbonel CA: Evaluación de la calidad del agua de la microcuenca del río Chibunga-Ecuador en variaciones estacionales, periodo 2013-2017. Revista del Instituto de Investigación de la Facultad de Ingeniería Geológica, Minera, Metalúrgica y Geográfica. 2018; 21(42): 13-26. Reference Source

Mátyás B, Chiluisa Andrade ME, Yandun Chida NC, et al.: Comparing organic versus conventional soil management on soil respiration [version 1; peer review: 2 approved]. F1000Res. 2018; 7: 258.

PubMed Abstract | Publisher Full Text | Free Full Text

Mátyás B, Lowy D, Singla A, et al.: Comparison of effects exerted by biofertilizers, NPK fertilizers, and cultivation methods on soil respiration in Chernozem soil. La Granja: Revista de Ciencias de la Vida. 2020; 32(2): 7-17. Publisher Full Text

Melendez: Raw data Chibunga. figshare. Dataset. 2021

http://www.doi.org/10.6084/m9.figshare.13875050.v1

Mendoza B: Characterization of real aquifers using hydrogeophysical measurements. An application to the Chambo aquifer (Ecuador). Ph. D. thesis, University of Calabria, Rende, Italy. 2016.

Mendoza B, Dama Research Center limited; Ltd., Genesis Sustainable Future: GPS Coordinates of Sampling Points in Guano and Chibunga basins. figshare. Dataset. 2021.

http://www.doi.org/10.6084/m9.figshare.13874696.v1

Naranjo C: Anuario meteorológico. Quito, Ecuador: Instituto Nacional de Meteorología e Hidrología (INAMHI). 2014; 130.

Reference Source

Ochoa-Tocachi BF, Buytaert W, Antiporta J, et al:: High-resolution

hydrometeorological data from a network of headwater catchments in the tropical Andes. Sci Data. 2018; 5: 180080.

PubMed Abstract | Publisher Full Text | Free Full Text

Pacheco Moya RM, Quiala Ortiz E, Martínez Hernández I: Determinación del parámetro número de curva en la cuenca Las Coloradas en un entorno SIG. Ingeniería Hidráulica y Ambiental. 2018; 39(2): 60-71.

Reference Source

Papierowska E, Matysiak W, Szatyłowicz J, et al.: Compatibility of methods used for soil water repellency determination for organic and organomineral soils. Geoderma. 2018; 314: 221-231.

Publisher Full Text

Sánchez-Cohen I, Velásquez-Valle MA, Esquivel-Arriaga G, et al.: Minimum hydrologic characterization for research in experimental watersheds with limited availability of information in arid lands. Revista Chapingo Serie Zonas Áridas. 2015; 14(2): 185-208.

Publisher Full Text

Satheeshkumar S, Venkateswaran S, Kannan R: Rainfall-runoff estimation using SCS-CN and GIS approach in the Pappiredipatti watershed of the Vaniyar sub basin, South India. Model Earth Syst Environ. 2017; 3(1): 24. Publisher Full Text

Sándor Zs, Tállai M, Kincses I, et al.: Effect of various soil cultivation methods on some microbial soil properties. DRC Sustainable Future. 2020; 1(1): 14-20. Publisher Full Text

Shomana T, Botha DE, Agachi PS: The water retention properties of biochar derived from broiler poultry litter as applied to the Botswana soil". DRC Sustainable Future. 2020; 1(1): 67-72.

Publisher Full Text

Sikorska AE, Viviroli D, Seibert J: Effective precipitation duration for runoff peaks based on catchment modelling. J Hydrology. 2018; 556: 510-522. Publisher Full Text

Singla A, Bautista G, Mátyás B, et al.: Altitudinal variations in $\mathbf{H}$ and $\mathbf{A l}$ ions interchange along with Fe content in Amazonian rainforest soil. La Granja: Revista de Ciencias de la Vida. 2018; 28(2): 42-50.

Publisher Full Text

Sukiasyan A, Kirakosyan A: Ecological evaluation of heavy metal pollution of different soil-climatic regions of Armenia by biogeochemical coefficients. DRC Sustainable Future. 2020; 1(2): 94-102.

Publisher Full Text

Tailor D, Shrimali NJ: Surface runoff estimation by SCS curve number method using GIS for Rupen-Khan watershed, Mehsana district, Gujarat. Indian Water Resour Soc. 2016; 36(4): 1-5.

Reference Source

TELEDET: «TELEDET - Percepción Remota,»Imágenes satelitales -

clasificación supervisada, [En línea]. 2017.

Reference Source

Toro EF: Riemann solvers and numerical methods for fluid dynamics: a practical introduction. Springer Science \& Business Media, 2013.

Publisher Full Text

Tso B, Mather P: Classification Methods for Remotely Sensed Data, CRC Presst. ISBN 1-4200-9072-0, 2009.

Publisher Full Text

Uwizeyimana D, Mureithi SM, Mvuyekure SM, et al.: Modelling surface runoff using the soil conservation service-curve number method in drought prone agro-ecological zone in Rwanda. International Soil and Water Conservation Research. 2019; 7(1): 9-17.

Publisher Full Text

Wang L, Tang L, Wang Z, et al.: Probabilistic characterization of the soilwater retention curve and hydraulic conductivity and its application to slope reliability analysis. Comput Geotech. 2020; 121: 103460.

Publisher Full Text

Wróbel M, Boczoń A: Determining the potential retention of a forest catchment based on the CN parameter. Model Earth Syst Environ. 2020; 1-4. Publisher Full Text

Zubieta R, Laqui W, Lavado W: Modelación hidrológica de la cuenca del río Ilave a partir de datos de precipitación observada y de satélite, periodo 2011-2015, Puno, Perú-Hydrological modeling using observed and satellite precipitation datasets for the Ilave River basin, 2011-2015 period, Puno, Peru. Tecnología y ciencias del agua. 2018; 9(5): 85-105.

Publisher Full Text 


\section{Open Peer Review}

\section{Current Peer Review Status:}

\section{Version 1}

Reviewer Report 26 November 2021

https://doi.org/10.5256/f1000research.31130.r92491

(C) 2021 Sutjiningsih D. This is an open access peer review report distributed under the terms of the Creative Commons Attribution License, which permits unrestricted use, distribution, and reproduction in any medium, provided the original work is properly cited.

\section{Dwita Sutjiningsih}

Department of Civil Engineering, Universitas Indonesia, Depok, Indonesia

The title should be added with the name of the country.

In general, the work is clearly and accurately presented and cites the current literatures as well, except the presentation of tables and figures. The table should be accompanied by the unit dimension of the variables involved, for example in Table 1, precipitation is in $\mathrm{mm}$. Figure 1 up to 3 are clear, but Figure 4-5 are a bit difficult to interpret, maybe it will be clearer if for each type of land cover, a relationship is made between precipitation and runoff.

The study design is appropriate, and the work is also technically sound. Sufficient details of methods and analysis are provided to allow replication by others.

Although it is presented in Spanish, the source data underlying the results are available and accessible to ensure full reproducibility.

The conclusions drawn however are very general, so without conducting any research, one can make such a statement. Conclusions should be made more specific. Also should be synchronized with the conclusion section in the abstract.

Note: Comment from Reviewer 1 that is not yet responded: Which one is used? A total of 23 points corresponding to the Chibunga river micro-basin and 21 points for the Guano river micro-basin (in "Analysis in the Laboratory") OR The 26 sampling points were in the Chibunga river micro-basin and 23 points in the Guano river micro-basin (in "Results and Discussion").

Is the work clearly and accurately presented and does it cite the current literature? Partly

Is the study design appropriate and is the work technically sound? Yes

Are sufficient details of methods and analysis provided to allow replication by others? 
Yes

If applicable, is the statistical analysis and its interpretation appropriate?

Yes

Are all the source data underlying the results available to ensure full reproducibility?

Yes

Are the conclusions drawn adequately supported by the results?

Partly

Competing Interests: No competing interests were disclosed.

I confirm that I have read this submission and believe that I have an appropriate level of expertise to confirm that it is of an acceptable scientific standard.

Reviewer Report 23 March 2021

https://doi.org/10.5256/f1000research.31130.r80799

(C) 2021 Benavides-Muñoz H. This is an open access peer review report distributed under the terms of the Creative Commons Attribution License, which permits unrestricted use, distribution, and reproduction in any medium, provided the original work is properly cited.

Holger Benavides-Muñoz

Universidad Técnica Particular de Loja (UTPL), Loja, Ecuador

General comments:

The article is within the scope of the F1000 Research Open for Science.

The abstract clearly explains the goal and the methodology as well as the flow of the paper. The method is well defined and well-illustrated as it is.

This reviewer believes that the authors are using pertinent equations with relevant variables which are clear to understand; besides, the authors detailed the laboratory procedures used in analyzing the associated analytical data.

Specific comments.-

On page 6, "The 26 sampling points were in the Chibunga river micro-basin and 23 points in the Guano river micro-basin." should be replaced by "The 23 sampling points were in the Chibunga river micro-basin and 21 points in the Guano river micro-basin." Please, the authors should verify these numbers.

Is the work clearly and accurately presented and does it cite the current literature? Yes

Is the study design appropriate and is the work technically sound? 
Yes

Are sufficient details of methods and analysis provided to allow replication by others? Yes

If applicable, is the statistical analysis and its interpretation appropriate?

Yes

Are all the source data underlying the results available to ensure full reproducibility? Yes

Are the conclusions drawn adequately supported by the results? Yes

Competing Interests: No competing interests were disclosed.

Reviewer Expertise: Hydraulic and environmental engineering

I confirm that I have read this submission and believe that I have an appropriate level of expertise to confirm that it is of an acceptable scientific standard.

The benefits of publishing with F1000Research:

- Your article is published within days, with no editorial bias

- You can publish traditional articles, null/negative results, case reports, data notes and more

- The peer review process is transparent and collaborative

- Your article is indexed in PubMed after passing peer review

- Dedicated customer support at every stage

For pre-submission enquiries, contact research@f1000.com 